Dinosaurian, was preoccupied by Marsh for a crocodile (1871). I therefore propose to name the Dinosaur mentioned (Nopcsa, Denkschriften R. Akad. Wissensch. Wien, 1899) Telmatosadrus.

Baron F. Nopcsa, Jun.

VIENNA, January $11 t h, 1903$.

\title{
GRANITE AND QUARTZ-VEINS.
}

Sir,-The paper by Mr. J. Lomas on "Quartz Dykes near Foxdale, Isle of Man," which appears in your January number (p. 34), raises an interesting question, and presents the argument in a cogent form. There can be no doubt that, on the fringe of a granite intrusion and in its apophyses, we sometimes find a gradual transition from normal granite, through various rocks which may be termed pegmatite, greisen, etc., to pure vein-quartz. Some phases of this transition are especially well displayed at Foxdale, a locality which I have already cited in this connection (Q.J.G.S., 1895, vol. li, pp. 143, 144), and which has now been described in detail by Mr. Lomas.

Closer inquiry is, however, necessary before we can be warranted in regarding such quartz-veins as igneous rocks in the ordinary sense. There are many indications, both from the geological and from the petrographical side, that the more siliceous products in question, and especially the pure quartz-veins, belong at most to the waning stage of igneous activity, when the temperature had fallen and the agency of water had become a more important factor. Dr. Sorby's well-known researches on fluid cavities, for instance, strongly support this view (Q.J.G.S., 1858, vol. xiv, pp. 471-475). But, further, there is sometimes reason to believe that, in these highly quartzose fringes and veins in very intimate connection with granite, a considerable part of the quartz has replaced felspar, and is therefore not strictly a primary mineral. One very clear example among others was described some years ago by Mr. Marr and myself on the edge of the Shap granite (Q.J.G.S., 1891, vol. xlvii, p. 285). Here distinct pseudomorphs of quartz after felspar put the question beyond doubt. In the greisens of Cornwall and Saxony, the beresite of the Urals, and such peculiar rocks as luxulyanite and trowlesworthite, the occurrence of special 'pneumatolytic' minerals like tin-stone, topaz, tourmaline, and fluor is equally convincing. We must recognize the possibility of a like origin for veins of quartz, or of quartz and mica, even where no direct evidence of replacement is preserved; and the existence of an igneous magma composed of pure, or nearly pure, silica cannot as yet be regarded as proved.

St. John's College, CamisRinge. Jamtary 17th, 1903.

THE TERM 'HEMERA.'

Sir,-Mr. Jukes-Browne seems to be haunted by the good word 'stratigraphical.' In the January number he finds fault with my 
table ${ }^{1}$ where certain strata are numbered to show their dates with regard to a column of hemera affixed. This he declares makes hemera a stratigraphical unit! Does he mean to say that in an ordinary calendar, when one has "Jan. 15 A B died; Jan. $16 \mathrm{YZZ}$ died," that thereby Jan. 15, 16 become, not time-units, not chronological indicators of the sequence, but the numbers of the tombs wherein the people are buried?

He takes another table, p. 519, "Correlation of Zones and Hemeræ," and says that that shows the hemeræ to be parts of a zone. In a diary one shows the correlation between certain events and certain days of the week. Does that make the days of the week parts of the events? The making of a piece of railway embankment by the deposit of so much earth is set down as occupying Monday and Tuesday; does that make these two days parts of a railway embankment? According to Mr. Jukes-Browne it does. A hemera (that is, Monday) is part of a zone (that is, the railway embankment) - so he says of a geological diary.

Having come to this remarkable conclusion he declares it is my fault that people supposed hemera was used in a stratigraphical sense, in spite of my distinct assertions to the contrary. Now I do begin to see how it is that people use terms incorreetly-they do not test them by expressions of every-day life. But that is their fault, not mine.

S. S. BuckMan.

\section{OBITUARY.}

ALFRED R. C. SELWYN, C.M.G., LL.D., F.R.S., F.G.S. Bors Ix 1824 .

Died November, 1902.

Bx the death of this distinguished geologist, Canada has lost one of her leading men of science. Dr. Selwyn was associated with the Geological Survey of Great Britain from 1845 to 1852 . In 1853 he was appointed by the Colonial Office Director of the Geological Survey of Victoria, Australia, a post which he held until 1869, when he retired owing to the Victorian Government refusing to vote the supplies necessary to carry on the work. Returning to England, on the retirement of Sir William Logan, Selwyn was at once appointed Director of the Canadian Geological Survey, a post which he held with distinction from 1869 to 1894, a period of 25 years, when he retired after 48 years of active and varied service, such as few men can lay claim to have seen, in three different and very distant quarters of the globe.

On his retirement he took up his residence in Vancouver, British Columbia, where for the past eight years he had enjoyed a well-earned leisure, dying at the age of 78 years. His life, accompanied by an excellent portrait, appeared in the Geological Magazine for February, 1899 (Dec. IV, Vol. VI, pp. 49-55, Pl. II). (See also Daily Chronicle, November 8th, 1902.)

H. W.

1 Quart. Journ. Geol. Soc., vol. xlix, facing p. 514. 